\title{
Desain dan Analisa Sistem Tenaga dan Transmsi pada Mobil Angkutan Multiguna Pedesaan Bertenaga Listrik
}

\author{
Dika Bayu Prasetyo, Unggul Wasiwitono, I Nyoman Sutantra \\ Teknik Mesin, Fakultas Teknologi Industri, Institut Teknologi Sepuluh Nopember (ITS) \\ e-mail: tantra@me.its.ac.id
}

\begin{abstract}
Abstrak-Kendaraan listrik merupakan salah satu solusi yang menjawab krisis energi pada zaman sekarang. Dalam perancangan kendaraan listrik yang terpenting adalah pemilihan motor yang digunakan, sehingga nantinya kinerja dari kendaraan listrik akan sama seperti kinerja dari kendaraan bertenaga bensin. Dalam penelitian ini akan dilakukan perhitungan rasio transmisi sehingga didapatkan kinerja yang terbaik dari kendaran multiguna pedesaan bertenaga listrik. Tahap pertama dalam pengerjaan studi ini dimulai dengan perhitungan dari gaya hambat kendaraan, sehingga kemudian didapatkan spesifikasi motor yang sesuai berdasarkan gaya hambat yang terjadi pada kendaraan. Perhitungan yang kedua adalah mengenai rasio transmisi dari kendaraan, setelah dilakukan perhitungan rasio transmisi maka dilakukan tahap analisa dari rasio transmisi. Sehingga didapatkan hasil analisa dari karakteristik traksi dan karakteristik power kendaraan. Pada penelitian ini didapat kesimpulan motor yang digunakan adalah Yasa Motor P400 series $25 \mathrm{kw}$, baterai LiFePO4 12V 100Ah dan rasio transmisi 1,87 tingkat pertama dan 0,348 tingkat kedua dengan rasio gardan sebesar 4,9.
\end{abstract}

Kata kunci-Gaya hambat, motor listrik, transmisi, traksi.

\section{PENDAHULUAN}

$\mathrm{P}$ ERKEMBANGAN industri otomotif di Indonesia mengalami kemajuan yang pesat pada periode 5 tahun kebelakang, khususnya dalam sektor mobil. Produksi mobil di Indonesia dari tahun 2011-2016 jumlahnya berada pada kisaran 1 juta unit [1]. Efek dari tingginya jumlah produksi tersebut adalah semakin besar konsumsi bahan bakar minyak yang digunakan sebagai sumber energi dari kendaraan [2].

Kendaraan multiguna pedesaan merupakan salah satu hasil karya dari Teknik Mesin ITS, dimana desain awal dari kendaraan ini adalah berbahan bakar bensin. Sebagai bentuk inovasi terhadap tingginya konsumsi bahan bakar maka kendaraan multiguna pedesaan didesain bertenaga listrik. Sebelumnya telah didesain kendaraan multiguna bertenaga hybrid oleh Saudari Indira Riska Saraswati, desain dari saudari Indira menggunakan motor $35 \mathrm{kw}$ [3]. Sistem transmisi yang digunakan oleh saudari Indira adalah 2 tingkat transmisi dengan rasio transmisi tingkat pertama adalah 3 dan yang kedua sebesar 0,7 . Kecepatan maksimal yang dapat ditempuh kendaraan adalah $80 \mathrm{~km} / \mathrm{jam}$.

Tujuan dari studi ini adalah didapatkan karakteristik traksi dan karakteristik power yang sesuai berdasarkan variasi sudut jalan yang dilalui kendaraan. Sehingga nanti dari studi ini akan diperoleh spesifikasi motor dan baterai yang digunakan serta rasio transmisi kendaraan.

\section{URAIAN PENELITIAN}

\section{A. Tahap Perhitungan}

Dalam pengerjaan studi ini awalnya dilakukan perhitungan terhadap gaya hambat yang terjadi pada kendaraan. Gaya hambat yang diperhitungkan dalam studi ini adalah gaya hambat angin, gaya hambat rolling dan gaya hambat tanjakan [4], sehingga nantinya dari ketiga gaya hambat tersebut didapat gaya hambat total berdasarkan variasi sudut tanjakan. Untuk dapat menghitung nilai dari gaya hambat angin dapat dilakukan berdasarkan persamaan 1 ,

$$
R_{a}=\frac{1}{2} \rho C_{d} A_{f} V^{2}
$$

Dimana $R_{a}$ adalah hambatan aerodinamika, $\rho$ adalah massa jenis udara, $C_{d}$ adalah koefisien drag, $A_{f}$ adalah luas frontal kendaraan, $V$ adalah kecepatan relative angin terhadap kendaraan. Sedangkan untuk gaya hambat rolling dapat dihitung dengan persamaan 2 ,

$$
\begin{aligned}
& R_{r}=f_{r} W \\
& f_{r}=f_{o}+f_{s}\left(\frac{v}{100}\right)^{2,5}
\end{aligned}
$$

Dimana $f_{r}$ adalah koefisien rolling, $f_{o}$ dan $f_{s}$ adalah koefisien yang nilainya tergantung pada tekanan ban dan $W$ adalah berat dari kendaraan. Gaya hambat tanjakan dapat dihitung menggunakan persamaan 4 ,

$$
R_{g}=W \sin \theta
$$

Dimana $\theta$ adalah sudut tanjakan jalan. Selanjutnya setelah mengetahui ketiga gaya hambat diatas maka dapat dihitung gaya hambat total pada kendaraan berdasarkan persamaan 5 dan 6 ,

$$
\begin{aligned}
& F_{r}=R_{a}+R_{r}+R_{g} \\
& F_{r}=\left(\frac{1}{2} \rho C_{d} A_{f} V^{2}\right)+\left(f_{r} W \cos \theta\right)+W \sin \theta
\end{aligned}
$$


Dimana $F_{r}$ adalah gaya hambat total kendaraan. Selanjutnya untuk dapat menentukan kebutuhan power yang dibutuhkan oleh kendaraan terlebih dahulu diketahui gaya hambat total dari kendaraan berdasarkan persamaan 6 , maka berdasarkan persamaan 7 dapat diketahui power yang diperlukan oleh kendaraan dimana $P$ merupakan power yang dibutuhkan oleh kendaraan karena gaya hambat.

$$
P=F_{r} V
$$

Karakteristik dari motor listrik adalah power yang dihasilkan akan bertambah dari kecepatan awal sampai kecepatan base, sedangkan dari kecepatan base sampai kecepatan maksimum power motor listrik akan relative konstan. Untuk torsi yang dihasilkan motor listrik adalah maksimum dari kecepatan awal sampai dengan kecepatan base, kemudian akan turun secara hyperbolic dari kecepatan base sampai kecepatan maksimum [4].

Disamping menentukan motor listrik yang digunakan penulis juga memperhitungkan baterai yang diperlukan oleh kendaraan. Untuk dapat menentukan kebutuhan baterai langkahlangkahnya adalah sebagai berikut,

1. Langkah pertama adalah menentukan durasi tembuh dari kendaraan.

2. Langkah kedua adalah menetukan besar kwh yang diperlukan baterai untuk memenuhi kebutuhan kendaraan.

3. Langkah ketiga adalah menentukan besar voltase pada baterai.

4. Langkah keempat adalah menghitung jelajah yang dapat ditempuh oleh kendaraan berdasarkan persamaan 8 , $s=t p$

dimana $s$ adalah jelajah kendaraan, $t$ adalah durasi tempuh kendaraan, $p$ adalah power baterai.

5. Langkah kelima adalah menghitung besar dari ampere baterai yang dibutuhkan. Dengan perumusan dibawah ini,

$$
A h=\frac{p}{v}
$$

dimana Ah adalah ampere yang dibutuhkan oleh baterai.

6. Langkah keenam adalah menghitung jumlah baterai yang diperlukan berdasarkan ketersediaan baterai dipasaran.

7. Langkah ketujuh adalah mendapatkan spesifikasi dari baterai yang diperlukan kendaraan.

Sistem transmisi kendaraan berfungsi mengkonversi torsi dan kecepatan dari sumber penggerak menjadi torsi dan kecepatan yang berbeda-beda kemudian diteruskan ke penggerak akhir. Langkah pertama menghitung rasio transmisi adalah menentukan rasio transmisi tingkat pertama dengan persamaan 10, dimana $F_{t}$ adalah gaya torsi kendaraan, $T_{m}$ adalah torsi mesin, $\eta_{t}$ adalah efisiensi dari transmisi, $r$ adalah jari-jari roda (m), $I_{d}$ adalah perbandingan gigi diferential.

$$
i_{1}=\frac{F_{t} r}{T_{m} i_{d} \eta_{t}}=\frac{\left(W \sin \theta_{\max }+f_{r} W+R_{a}\right) r}{T_{m} i_{d} \eta_{t}}
$$

Setelah menghitung rasio tingkat pertama selanjutnya adalah menghitung rasio tingkat akhir dan selanjutnya ditentukan tingkat transmisi yang digunakan pada kendaraan.Untuk menghitung rasio transmisi tingkat akhir menggunakan persamaan 11 ,

$$
i_{2}=\frac{F_{t} r}{T_{m} i_{d} \eta_{t}}=\frac{\left(f_{r} W+\frac{1}{2} C_{d} A_{f} V\right) r}{T_{m} i_{d} \eta_{t}}
$$

Tahap analisa yang digunakan untuk melihat hasil dari rasio transmisi adalah dengan karakteristik traksi dan karakteristik power yang dihasilkan oleh rasio transmisi. Dengan menghitung kecepatan base dan kecepatan maksimum serta gaya dorong minimum dan gaya dorong maksimum yang dihasilkan tiap transmisi maka akan didapat karakteristik traksi dari kendaraan, dibawah ini merupakan perumusan untuk menghitung karakteristik traksi tersebut, dimana $V_{b}$ adalah kecepatan base transmisi, $V_{\max }$ adalah kecepatan maksimum transmisi, $N_{b}$ adalah putaran base dari motor listrik, $N_{\max }$ adalah putaran maksimum dari motor listrik.

$$
\begin{aligned}
& V_{b}=\frac{\pi r N_{b}}{30 I_{t} I_{d}} \\
& V_{\text {max }}=\frac{\pi r N_{\text {max }}}{30 I_{t} I_{d}} \\
& F_{t \text { max }}=\frac{I_{t} I_{d} T_{\text {max }} \eta_{t}}{r} \\
& F_{t \text { min }}=\frac{I_{t} I_{d} T_{\text {min }} \eta_{t}}{r}
\end{aligned}
$$

Untuk karakteristik power yang dihasilkan dari rasio transmisi dapat dianalisa dengan membandingkan power yang dihasilkan kendaraan dengan power yang ditimbulkan oleh gaya hambat. Power dari transmisi dan power yang ditimbulkan oleh gaya hambat dapat dihitung menggunakan persamaan 7 dan 16 ,

$$
P_{t}=F_{t} V
$$

dimana $P_{t}$ adalah power dari transmisi kendaraan .

\section{HASIL DAN ANALISA}

\section{A. Data dan Spesifikasi Kendaraan}

Data dan spesifikasi kendaraan dapat dilihat Tabel 1 pada lampiran.

\section{B. Perhitungan Spesifikasi dari Motor dan Baterai}

Berdasarkan persamaan 7 mengenai perhitungan power dari kendaraan terlebih dahulu harus diketahui gaya hambat total yang terjadi pada kendaraan. Untuk dapat menghitung gaya hambat total yang terjadi pada kendaraan dapat digunakan persamaan 5 dan 6, pada Gambar 1 penulis membandingkan 
gaya hambat total pada kendaraan berdasarkan variasi sudut tanjakan dengan pengaruh kecepatan.

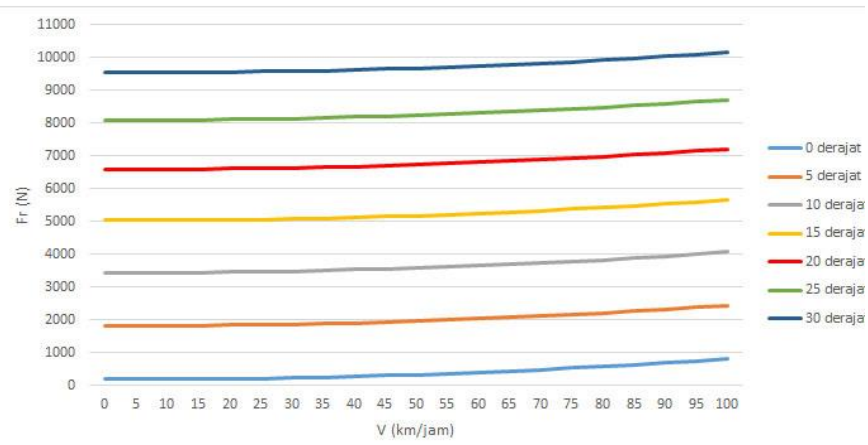

Gambar 1. Gaya hambat total berdasarkan variasi sudut tanjakan dan kecepatan kendaraan

Pada grafik Gambar 1 menunjukkan pengaruh kecepatan dan variasi sudut tanjakan terhadap gaya hambat total, semakin besar sudut tanjakan dan kecepatan kendaraan maka semakin besar pula gaya hambat yang terjadi.

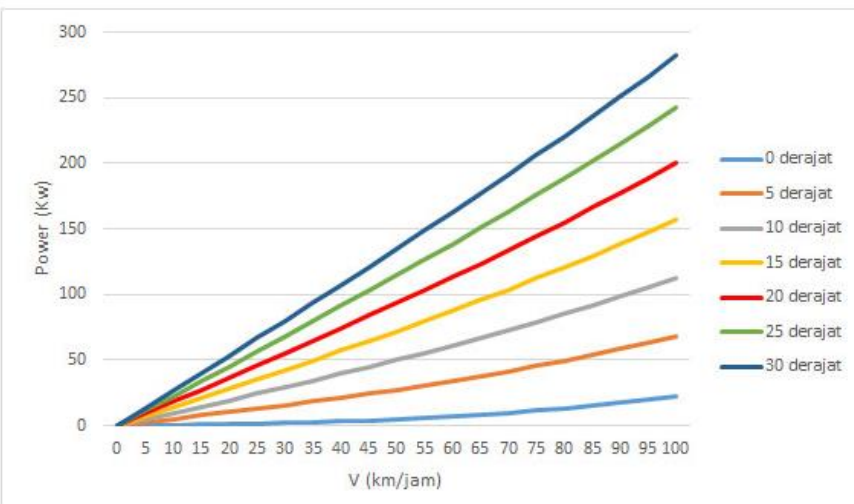

Gambar 2. Kebutuhan daya kendaraan

Setelah mengetahui gaya hambat total pada kendaraan berdasarkan gambar 1, selanjutnya menghitung kebutuhan daya kendaraan berdasarkan persamaan 7 sehingga mendapatkan grafik seperti pada gambar 2. Berdasarkan grafik pada gambar 2 apabila penulis menginginkan kendaraan untuk melaju pada sudut tanjakan 30 derajat dengan kecepatan $20 \mathrm{~km} / \mathrm{jam}$ maka penulis memerlukan power sebesar 50kw. Berdasarkan grafik tersebut maka digunakan motor YASA P400Series dengan power sebesar $25 \mathrm{kw}$. Seperti spesifikasi tabel 2 pada lampiran.

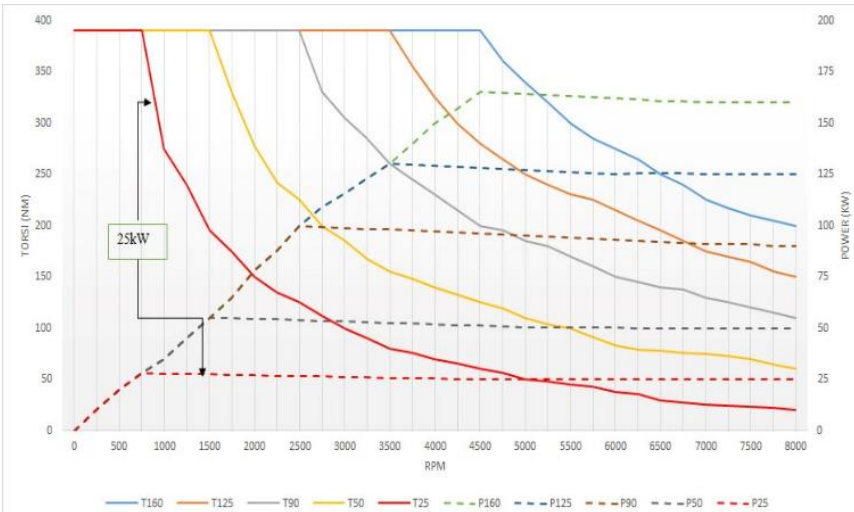

Gambar 3.Torsi dan Power Motor YASA P400 Series 25Kw
Berdasarkan gambar 3 menunjukkan karakteristik dari power dan torsi yang dihasilkan oleh Motor YASA P400Series. Dimana kecepatan base akan semakin kecil apabila power yang digunakan juga semakin kecil. Pada power maksimal dari motor yaitu $160 \mathrm{~kW}$ kecepatan base yang dihasilkan adalah $4500 \mathrm{rpm}$, karena penulis menggunakan power sebesar $25 \mathrm{~kW}$ maka kecepatan base yang dihasilkan adalah $750 \mathrm{rpm}$.

Selanjutnya untuk baterai yang digunakan oleh kendaraan multiguna pedesaan bertenaga listrik adalah $\mathrm{LiFePO} 412 \mathrm{v}$ 110Ah. Hal ini didapatkan dari perhitungan bahwa durasi tempuh dari kendaraan $(\mathrm{t})$ adalah $6,3 \mathrm{~km} / \mathrm{kwh}$, power baterai $(\mathrm{p})$ $12,5 \mathrm{kw}$, voltase baterai (v) $125 \mathrm{volt}$. Maka berdasarkan perumusan 8 didapatkan jelajah dari kendaraan adalah sebesar $78,75 \mathrm{~km}$. Selanjutnya untuk mendapatkan kebutuhan ampere dari baterai menggunakan perumusan 9 dan hasilnya adalah sebesar $100 \mathrm{Ah}$. Setelah menentukan spesifikasi dari baterai adalah LiFePo4 12V 110Ah, maka ditentukan jumlah baterai yang dibutuhkan adalah power baterai yang dibutuhkan dibagi dengan power tiap baterai dan hasilnya dalah membutuhkan 11 pack baterai. Untuk data dan spesifikasi dari baterai dapat dilihat tabel 3 pada lampiran.

\section{Perhitungan Rasio Transmisi}

Perhitungan rasio transmisi dilakukan dengan menghitung pada tingkat pertama, berdasarkan perumusan 10 penulis mendapatkan hasil rasio transmisi tingkat pertama adalah sebesar 1,87 . Sedangkan untuk selanjutnya adalah menghitung rasio transmisi tingkat akhir berdasarkan perumusan 11 dan hasilnya adalah 0,348. Jadi penulis menggunakan rasio transmisi tingkat pertama adalah 1,87 dan 0,348 pada tingkat kedua. Selanjutnya setelah diketahui rasio transmisi pada masing-masing tingkat maka harus dihitung nilai dari kecepatan base dan kecepatan maksimum berdasarkan perumusan 12 dan 13, maka didapat kecepatan base pada transmisi pertama $\left(\mathrm{V}_{1 \mathrm{~b}}\right)$ adalah sebesar 10,14 km/jam dan kecepatan maksimum pada transmisi pertama $\left(\mathrm{V}_{1 \max }\right)$ adalah $67,6 \mathrm{~km} / \mathrm{jam}$. Sedangkan untuk kecepatan base transmisi kedua $\left(\mathrm{V}_{2 \mathrm{~b}}\right)$ adalah $54,6 \mathrm{~km} / \mathrm{jam}$ dan kecepatan maksimum transmisi kedua $\left(\mathrm{V}_{2 \max }\right)$ adalah 109 $\mathrm{km} / \mathrm{jam}$. Selain menghitung kecepatan base dan kecepatan maksimum maka harus dihitung pula gaya dorong maksimum dan minimum berdasarkan perumusan 14 dan 15, untuk gaya dorong maksimum transmisi pertama $\left(\mathrm{Ft}_{1 \max }\right)$ adalah $9775,9 \mathrm{~N}$ dan gaya dorong minimum transmisi pertama $\left(\mathrm{F}_{1 \mathrm{~min}}\right)$ adalah $1253,33 \mathrm{~N}$ sedangkan gaya dorong maksimum transmisi kedua $\left(\mathrm{F}_{2 \max }\right)$ adalah $1816,52 \mathrm{~N}$ dan gaya dorong minimum transmisi kedua $\left(F_{2 \min }\right)$ adalah $908,26 \mathrm{~N}$. Maka selanjutnya rancangan rasio transmisi dianalisa berdasarkan karakteristik traksi dan power seperti pembahasan D dan E.

\section{Analisa Karakteristik Traksi Kendaraan}

Pada Gambar 8 menunjukkan karakteristik traksi yang dihasilkan oleh rancangan rasio transmisi. Berdasarkan perhitungan didapat kecepatan base pada transmisi pertama adalah $10,14 \mathrm{~km} / \mathrm{jam}$ dan $54,6 \mathrm{~km} / \mathrm{jam}$ pada tingkat kedua. Sedangkan untuk kecepatan maksimum pada transmisi pertama adalah $67,6 \mathrm{~km} / \mathrm{jam}$ dan $109 \mathrm{~km} / \mathrm{jam}$ untuk transmisi kedua. Untuk kemampuan dari kendaraan terlihat pada sudut tanjakan maksimum adalah sebesar $11 \mathrm{~km} / \mathrm{jam}$, sedangkan kecepatan maksimum kendaraan pada transmisi pertama adalah sebesar 60 $\mathrm{km} / \mathrm{jam}$ pada kondisi jalan mendatar dan permukaan jalan aspal. 
Pada transmisi kedua kendaraan dapat melewati medan jalan dengan sudut tanjakan 5 derajat sebesar $45 \mathrm{~km} / \mathrm{jam}$, sedangkan untuk jalan aspal dengan menggunakan transmisi kedua dapat menghasilkan kecepatan maksimal sebesar $68 \mathrm{~km} / \mathrm{jam}$. Untuk kecepatan akhir yang dapat dihasilkan adalah lebih dari 100 $\mathrm{km} / \mathrm{jam}$ pada kondisi jalan mendatar.

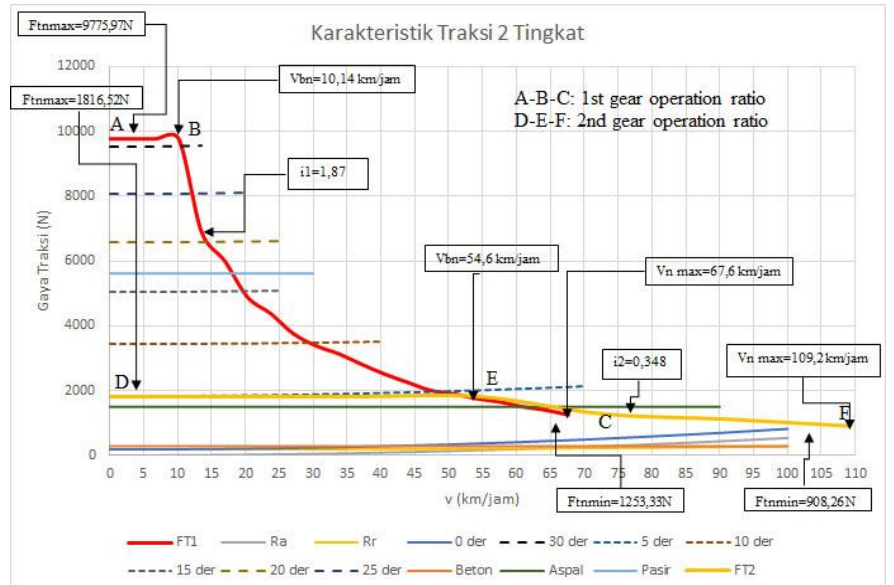

Gambar 8. Karakteristik Traksi Kendaraan Multiguna Bertenaga Listrik

\section{E. Analisa Karakteristik Power Kendaraan}

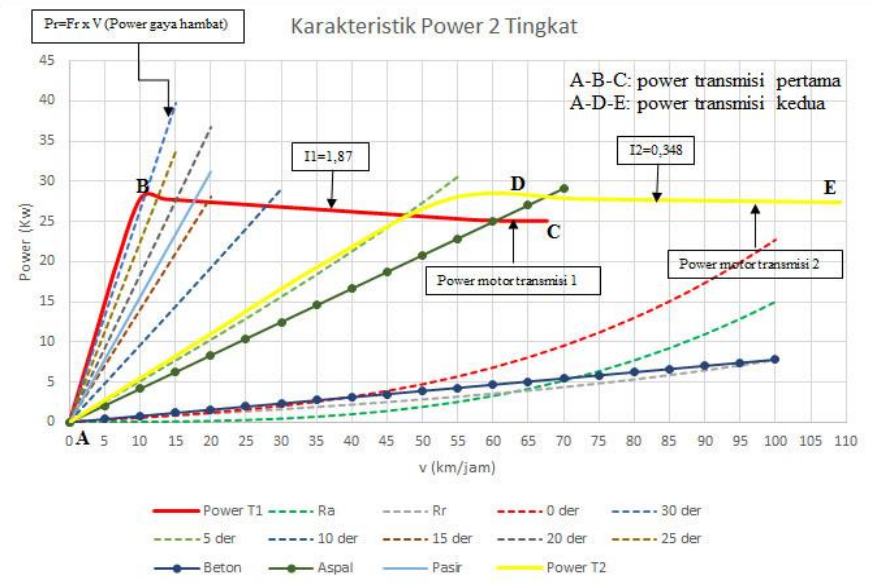

Gambar 9. Karakteristik Power Kendaraan Multiguna Pedesaan Bertenaga Listrik

Berdasarkan Gambar 9, pada transmisi pertama power maksimum dari motor digunakan seluruhnya pada sudut 30 derajat dan menghasilkan kecepatan maksimum sebesar 11 $\mathrm{km} / \mathrm{jam}$. Untuk jalanan pasir yang dilalui kendaraan kecepatan maksimum yang dapat dihasilkan adalah $18 \mathrm{~km} / \mathrm{jam}$ dengan power dari motor digunakan seluruhnya untuk memenuhi kebutuhan power dari gaya hambat. Kecepatan maksimum yang dapat dihasilkan adalah $60 \mathrm{~km} / \mathrm{jam}$, hal ini karena pada jalan aspal power keseluruhan dari motor sama dengan power yang dibutuhkan pada gaya hambat. Power total yang digunakan pada motor adalah $25 \mathrm{kw}$. Sedangkan pada transmisi kedua power yang dihasilkan oleh motor dapat melalui medan jalan yang mempunyai sudut tanjakan 5 derajat, kecepatan yang dihasilkan pada kondisi tersebut adalah $45 \mathrm{~km} / \mathrm{jam}$ dengan kosumsi power sebesar $23 \mathrm{kw}$. Pada jalan aspal transmisi kedua mampu menghasilkan kecepatan yang lebih besar dari transmisi pertama yaitu sebesar $68 \mathrm{~km} / \mathrm{jam}$, hal ini karena power yang dihasilkan motor sama besarnya dengan power yang dibutuhkan akibat gaya hambat. Untuk kecepatan maksimum yang dapat dihasilkan oleh transmisi kedua adalah lebih dari $100 \mathrm{~km} / \mathrm{jam}$ pada jalan mendatar.

\section{KESIMPULAN}

Setelah melakukan analisa perhitungan dan pembahasan maka dapat diambil kesimpulan sebagai berikut:

1. Berdasarkan perhitungan yang telah dilakukan, maka besar gaya hambat yang terjadi adalah 538,67 $\mathrm{N}$ untuk gaya hambat angin pada kecepatan $100 \mathrm{~km} / \mathrm{jam}, 281,06 \mathrm{~N}$ untuk gaya hambat rolling pada jalan mendatar dengan kecepatan $100 \mathrm{~km} / \mathrm{jam}$ dan 9368,6 N untuk gaya hambat pada tanjakan 30 derajat.

2. Berdasarkan rasio transmisi yang digunakan pada tingkat pertama dengan gaya traksi sebesar $9775,97 \mathrm{~N}$ kendaraan dapat melewati sudut tanjakan 30 derajat pada kecepatan $11 \mathrm{~km} / \mathrm{jam}$ dan dengan gaya traksi sebesar $1500 \mathrm{~N}$ kendaraan dapat melaju pada kecepatan $60 \mathrm{~km} / \mathrm{jam}$ di jalan aspal, berdasarkan perhitungan kendaraan dapat melaju dengan transmisi pertama sampai dengan kecepatan 67 $\mathrm{km} / \mathrm{jam}$. Sedangkan untuk tingkat transmisi kedua dengan gaya traksi sebesar $1818,97 \mathrm{~N}$ kendaraan dapat melaju 65 $\mathrm{km} / \mathrm{jam}$ pada jalan aspal, dan berdasarkan perhitungan kecepatan maksimum pada transmisi kedua adalah sebesar $109,2 \mathrm{~km} / \mathrm{jam}$.

3. Berdasarkan karakteristik power yang terjadi menunjukkan hasil yang tidak terlalu berbeda dengan hasil karakteristik traksi kendaraan. Dimana dengan power maksimum dari motor listrik dapat melewati sudut tanjakan 30 derajat dengan kecepatan $11 \mathrm{~km} / \mathrm{jam}$ pada transmisi pertama dan dengan power maksimum dari motor berdasarkan analisa karakteristik power pada transmisi pertama dapat melaju sebesar $60 \mathrm{~km} / \mathrm{jam}$ pada jalan aspal. Sedangkan pada karakteristik power pada transmisi kedua menunjukkan kemampuan kendaraan berdasarkan power maksimum kendaraan dapat melaju pada jalan aspal sebesar $68 \mathrm{~km} / \mathrm{jam}$ dan dapat menghasilkan kecepatan maksimum 109,2 $\mathrm{km} / \mathrm{jam}$ dengan menggunakan power maksimum dari kendaraan.

\section{LAMPIRAN}

Tabel 1.

Data dan Spesifikasi Kendaraan

\begin{tabular}{ll}
\hline \hline Dimensi & \\
\hline Jarak sumbu roda & $2590 \mathrm{~mm}$ \\
Lebar & $1440 \mathrm{~mm}$ (depan) \\
Tinggi & $1480 \mathrm{~mm}$ (belakang) \\
Ground clearance & $2260 \mathrm{~mm}$ \\
Massa & $240 \mathrm{~mm}$ \\
Massa rolling chassis, motor dan baterai & $910 \mathrm{~kg}$ \\
Berat box penumpang & $500 \mathrm{~kg}$ \\
Berat beban maksimum & $500 \mathrm{~kg}$ \\
Ban & \\
4 roda tunggal & Radial (P 165/80 R13) \\
\hline \hline
\end{tabular}


Tabel 2.

Data dan Spesifikasi Motor

\begin{tabular}{lll}
\hline \hline Peak power & $160 \mathrm{~kW}$ & \\
Peak torque & $390 \mathrm{Nm}$ & \\
Continuous Power & $20 \mathrm{~kW}$ to $100 \mathrm{~kW}$ & \\
Speed & $0-8000 \mathrm{rpm}$ & \\
Peak Efficiency & & $96 \%$ \\
Dry Mass & $24 \mathrm{~kg}$ & \\
\hline \hline
\end{tabular}

Tabel 3.

Data dan Spesifikasi Baterai

\begin{tabular}{ll}
\hline \hline Jenis & LiFePO4 \\
Power & $12,5 \mathrm{kw}$ \\
Voltase & $125 \mathrm{volt}$ \\
Ampere & $100 \mathrm{Ah}$ \\
Jumlah & 11 pack \\
Massa & $60 \mathrm{~kg}$ \\
\hline \hline
\end{tabular}

DAFTAR PUSTAKA

[1] GAIKINDO, "Domestic Auto Production." Jakarta, 2016.

[2] B. MIGAS, "Konsumsi BBM Nasional," 2016. [Online]. Available: http://www.bphmigas.go.id/konsumsi-bbm-nasional.

[3] S. R. I. Riska, "Analisa Rancangan Rasio Transmisi dan Kinerja Traksi pada Kendaraan Produksi Multiguna Pedesaan,” 2015.

[4] S. . Nyoman, Teknologi Otomotif Hybrid, Institut Teknologi Sepuluh Nopember. Guna Widya, 2015. 